\title{
Strength of pelvic floor in men: reliability intra examiners
}

\author{
Força dos músculos do assoalho pélvico em \\ homens: confiabilidade intraexaminadores
}

\section{Fuerza de los músculos del piso pélvico en hombres: confiabilidad intraexaminadores}

\author{
Patricia Zaidan $^{[a, b]}$, Fabio Dutra Pereira ${ }^{[b]}$, Elirez Bezerra da Silva ${ }^{[b]^{*}}$ \\ [a] Hospital Federal do Estado do Rio de Janeiro (HFSE), Rio de Janeiro, RJ, Brazil \\ [b] Universidade do Estado do Rio de Janeiro (UERJ), Rio de Janeiro, RJ, Brazil
}

\begin{abstract}
Introduction: The obtaining of urinary continence is due to the strength of the pelvic floor muscles (MAPs) at the moment of muscle contraction, when there are sudden increases in intra-abdominal pressure, which increases urethral closure pressure and decreases the possibility of urinary loss. Objective: To verify the reliability, type: stability, intra-examiner, of the measure of the strength of MAPs held with Peritron. Methods: Test and retest study to assess the intra-rater reliability of Peritron to measure the strength of MAPs. The sample consisted of 36 male patients, mean age $65.3 \pm 7.2$ years, all with urinary incontinence (UI) after radical prostatectomy. The physical therapist conducted a training for familiarization with the procedures of MAPs strength assessment with Peritron for two weeks. The strength of MAPs was measured by a perineometer of the Peritron brand (PFX 9300®, Cardio-Design Pty. Ltd, Baulkham Hills, Australia, 2153). Results: The intraclass correlation coefficient (ICC) was equal to $0.99 ; \mathrm{P}=0.0001$.
\end{abstract}

*PZ: Doctoral Student, e-mail: patriciazaidan@gmail.com FDP: PhD, e-mail: profabiodutra@gmail.com EBS: PhD, e-mail: elirezsilva@cosmevelho.com.br 
The typical measurement error (ETM) was equal to $3.1 \mathrm{cmH}_{2} \mathrm{O}$ and ETM\% of 4. Conclusion: Peritron showed high reliability for measuring the strength of MAPs in men, both for clinical practice and for the production of scientific knowledge. It should be noted that such measures were carried out in stability, so it is suggested that in internal consistency reliability is equivalent.

Keywords: Stability. Reliability. Muscle strength. Pelvic floor.

\section{Resumo}

Introdução: A força de contração dos músculos do assoalho pélvico (MAPs) pode contribuir para a continência urinária, quando ocorrem súbitos aumentos de pressão intra-abdominal. Objetivo: Verificar a confiabilidade, tipo estabilidade, intraexaminador, da medida da força dos MAPs, realizada com o Peritron. Métodos: Estudo de teste e reteste para avaliar a confiabilidade intra-avaliador do Peritron para medir a força dos MAPs. A amostra foi composta por 36 pacientes do sexo masculino, com média de idade de 65,3 \pm 7,2 anos, todos com incontinência urinária (IU) após prostatectomia radical. 0 fisioterapeuta realizou um treinamento para familiarização com os procedimentos de avaliação da força dos MAPs com o Peritron, durante duas semanas. A força dos MAPs foi medida por um perineômetro da marca Peritron (PFX $9300 ®$, Cardio-Design Pty. Ltd, Baulkham Hills, Austrália, 2153). Resultados: O CCI foi igual a 0,99; P=0,0001. $O$ ETM foi igual a 3,1 $\mathrm{cmH}_{2} \mathrm{O}$ e o ETM\% igual a 4. Conclusão: o Peritron mostrou elevada confiabilidade para medir a força dos MAPs em homens, tanto para a prática clínica quanto para a produção de conhecimento científico. Cabe ressaltar que tais medidas foram realizadas em estabilidade, portanto, sugere-se que em consistência interna sua confiabilidade seja equivalente.

Palavras-chave: Estabilidade. Confiabilidade. Força muscular. Assoalho pélvico.

\section{Resumen}

Introducción: La obtención de la continencia urinaria es debido a la fuerza de los músculos del piso pélvico (MAPs) en el momento de su contracción muscular, cuando ocurren súbitos aumentos de presión intraabdominal, lo que aumenta la presión de cierre uretral y disminuye la posibilidad de pérdida de la orina. Objetivo: Verificar la confiabilidad, tipo estabilidad, intra examinador, de la medida de la fuerza de los MAPs, realizada con el Peritrón. Métodos: Estudio de prueba y reprueba para evaluar la confiabilidad intra-evaluadora del Peritrón para medir la fuerza de los MAPs. La muestra fue compuesta por 36 pacientes del sexo masculino, la media de edad era de 65,3 \pm 7,2 años, todos con IU después de la prostatectomía radical. El fisioterapeuta realizó un entrenamiento para familiarización de los procedimientos de evaluación de la fuerza de los MAPs con el Peritrón, durante dos semanas. La fuerza de los MAPs fue medida por un perineómetro de la marca Peritron (PFX 9300®, Cardio-Design Pty., Ltd, Baulkham Hills, Australia, 2153). Resultados: El coeficiente de correlación intraclase (CCI) fue igual a 0,99; P=0,0001. El error típico de la medida (ETM) fue igual a 3,1 $\mathrm{cmH}_{2} \mathrm{O}$ y el ETM\% igual a 4. Conclusión: el Peritrón mostró elevada confiabilidad para medir la fuerza de los MAPs en hombres, tanto para la práctica clínica y para la producción del conocimiento científico. Cabe resaltar que tales medidas se realizaron en estabilidad, por lo que se sugiere que en consistencia interna su confiabilidad sea equivalente.

Palabras clave:Estabilidad. Confiabilidad. Fuerza muscular. Piso pélvico. 


\section{Introduction}

The assessment of the strength of the pelvic floor muscles (MAPs) provides the perception of the contraction capacity of these muscles, however it is not an easy task and so far no study has been performed to verify the reliability of an instrument to measure contraction force of these muscles in men [1]. The contraction force of the MAPs may contribute to urinary continence, when there are sudden increases in intra-abdominal pressure, with increased urethral closure pressure and a decrease in the possibility of urinary loss [1 - 3].

The assessment of the state of a muscle at rest and during maximal voluntary muscle contraction is necessary when re-training a muscle, which makes it possible to compare clinical data before and after an intervention with muscle exercises [4]. The strength of the MAPs is important for evaluation, prescription and follow-up of programs aimed at restoring urinary continence resulting from radical prostatectomy [5 - 8].

The evaluation of the strength of the MAPs by digital palpation, using the modified Oxford Scale, is the evaluation method most used by physiotherapists because it is costless and practical. However, scientifically, it is a questioned condition because the force of contraction is graded subjectively. In addition, the use of the Scale is appropriate only for women [9 - 11].

An objective way to evaluate the strength of the MAPs with strong reliability is the perineometry performed from the measurement of the strength of these muscles with the Peritron (ICC $=0.95,95 \%$ CI 0.88-0.98) because the pressure readings are a proxy measure of strength $[11,12]$, which facilitates the prescription and evaluation of the efficacy of treatment to patients. However, the reliability of the measurement of the strength of the MAPs presented was from a study carried out with women and, after a review in the scientific databases MEDLINE, BVS, SciELO, Scirus and Redalyc, no Peritron reliability study for men was found.

In the absence of studies and given the need for a reliable instrument to evaluate the contraction force of the MAPs in men, the objective of this study was to verify the reliability, intra-examiner, of the measurement of the strength of the MAPs, performed with Peritron.

\section{Methods}

This study was developed in the Stricto Sensu PostGraduation Program in Exercise and Sports Sciences of the State University of Rio de Janeiro, UERJ, RJ-Brazil, in the Pelvic Physiotherapy sector of the Urology Outpatient Clinic of the Federal Hospital of Rio de Janeiro (HFSE), drafted in accordance with the Guidelines for Reporting Reliability and Agreement Studies (GRRAS) [13]. All procedures followed the Brazilian guidelines and standards for research involving human beings set forth in Resolution 466 of December 12, 2012 from the National Council of Health [14] and its approval was given by the consubstantiated opinion of protocol $\mathrm{n}^{-}$06436712.0.0000.5287.

\section{Study design}

This was a test and retest study to evaluate the intrarater reliability of Peritron to measure the strength of MAPs in men.

\section{Participants}

Thirty-six male patients were included in the study; meanage was $65.3 \pm 7.2$ years, all of them with sphincteric UI consequent to retropubic radical prostatectomy surgery, with the maximum postoperative time of up to six months; who used 2 to 5 disposable protectors per day. Patients were excluded from the study when they presented symptoms of urinary tract infection; symptoms of lower urinary tract obstruction; anal fistula; previous radiotherapy; and when they did not undergo transurethral resection of the prostate.

The patients, after being referred from the HFSE Urology to the Pelvic Physiotherapy Clinic, underwent an assessment of the strength of the MAPs made by a physiotherapist specialized in Pelvic Physiotherapy, at the same time, in the same place and in the same environmental conditions. The physiotherapist underwent training to familiarize themselves with the strengths of the MAP with Peritron for two weeks, with the physiotherapist experienced in the use of the equipment.

\section{MAP strength measuring instrument}

The strength of the MAPs was measured by a Peritron brand perineometer (PFX $9300^{\circledR}$, Cardio-Design Pty. Ltd, Baulkham Hills, Australia, 2153). Peritron is a perineum that measures anal pressure in centimeters of water $\left(\mathrm{cmH}_{2} \mathrm{O}\right)$, indirectly quantifying the strength of the 
MAPs by means of a sensor connected to a portable microprocessor with a latex tube.

Procedures for measuring the strength of MAPs

Patients became familiarized with three contractions and after two or four days the first measurement of strength of the MAPs (test) with Peritron was performed. Two days later, the second measurement of MAP strength (retest) was performed. None of the participants underwent training of pelvic floor muscles prior to participating in the survey or between the two moments of MAP strength measurement. All were able to voluntarily contract and completely relax their MAPs.

The patient was placed in lateral decubitus with knees and hip flexed, naked from the waist down. The physiotherapist introduced the perineometer sensor into the anal canal with one hand and the other hand placed over the abdomen to control the concomitant contraction of this muscle with the MAPs. The anal pressure was then measured with a seamless medical grade silicone elastomer sensor. The sensor is connected to a portable microprocessor with a latex tube, allowing the measurement of the contraction pressure exerted by the pelvic floor musculature in centimeters of water $\left(\mathrm{cmH}_{2} \mathrm{O}\right)$, thus quantifying the indirect force of the MAPs. The pressure gauge readings are a proxy measure of force [15]. The instrument was calibrated to zero before each measurement. The anal sensor has not been inflated. According to the manufacturer, inflation is an optional feature that can reduce the sensitivity of the sensor response. Patients were instructed to perform three maximal muscle contractions of the pelvic floor with an interval of 30 seconds between them, as reported in a study by Barbosa et al. [12] Hip and adductor hip contractions were discouraged, as was the Valsalva maneuver $[11,15]$ The maximum value of the three contractions was recorded.

\section{Statistical analysis}

In order to analyze the intra-assay reliability of the Peritron perineometer, the intraclass correlation coefficient (ICC) and the typical measurement error (TME) [16] were used. The Bland and Altman confidence limits were used for the exclusion of outliers. The data were analyzed in SPSS version 18.0 packages (SPSS Inc., USA) and Statistica 6.0 (StatSoft, USA).

\section{Results}

The deviations between test and retest were equal to $0.1 \pm 6.5 \mathrm{cmH}_{2} \mathrm{O}$, the Bland \& Altman confidence limits were -12.7 to $13.0 \mathrm{cmH}_{2} \mathrm{O}$. An outlier was excluded because it presented deviation equal to $28.3 \mathrm{cmH}_{2} \mathrm{O}$ (Figure 1). The first measure of MAP strength (test) was $83.8 \pm 52.0 \mathrm{cmH}_{2} \mathrm{O}$. The second measure of MAP strength (retest) was $84.5 \pm 52.6 \mathrm{cmH}_{2} \mathrm{O}$. The intraclass correlation coefficient (ICC) was $0.99 ; \mathrm{P}=0.0001$. The typical measurement error (TME) was $3.1 \mathrm{cmH}_{2} \mathrm{O}$ and the TME $\%$ was equal to 4 .

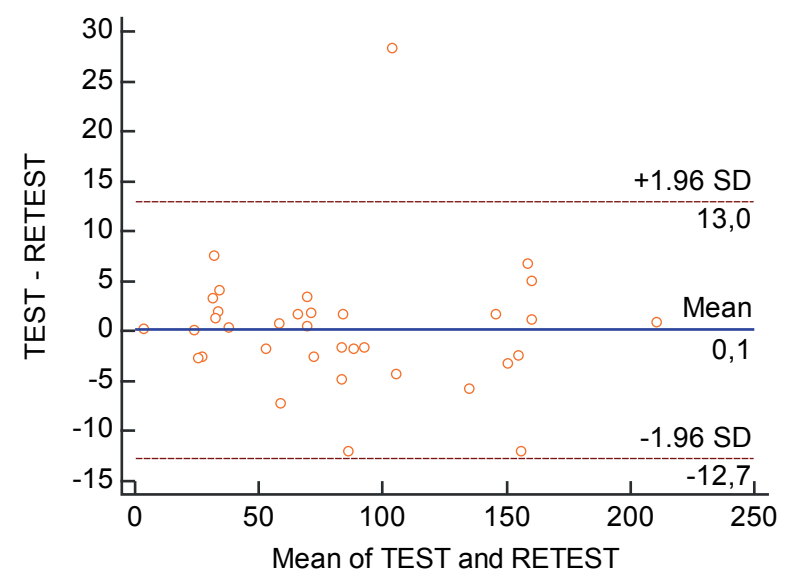

Figure 1 - Bland \& Altman confidence limits for MAPS strength measures with Peritron.

\section{Discussion}

The ICC equal 0.99; $\mathrm{P}=0.0001$, the TME equal $3.1 \mathrm{cmH}_{2} \mathrm{O}$ and the TME\% equal 4 obtained in the present study showed a strong intra-rater reliability for the measurement of strength of the MAPs with the Peritron perineometer. Observing Figure 1, the minimum strength value of MAPs was $3.6 \mathrm{cmH}_{2} \mathrm{O}$ and maximum of $211.3 \mathrm{cmH}_{2} \mathrm{O}$, both with a test and retest difference close to zero, showing that Peritron can be reliable in measuring both levels of high intensity strength of the MAPs.

The above-mentioned reliability of Peritron to measure the strength of MAPs is very important for both research and clinical care of patients. For both situations, 
the study design and the statistics used showed that both the researcher and the physiotherapist could use Peritron to obtain reliable results in the research and evaluation of patients.

The reliability obtained in the present study was previously replicated in another study with women, which evaluated the strength of the MAPs by vaginal pressure (ICC $=0.95,95 \%$ CI 0.88-0.98) $[11,17]$. In both situations, for both men and women, reliability was adequate for clinical practice, because in addition to being statistically significant $(\mathrm{P}=0.0001)$, the ICC was higher than 0.93 and the TME less than $9 \%$, cutoff points admitted as low risk to this practice [13]. Analyzing the strength of evidence on the basis of a sample size of studies that tested the reliability of Peritron in women, $(n=20)$ [11] and $(n=19)$ [17], this study stands out by having a higher sample size $(n=36)$.

The strength of the MAPs is one of the most important factors for continence, since fast and strong contractions of the MAPs result in the generation of adequate closure pressure in the proximal urethra, which maintains a higher pressure than in the bladder, thus preventing the loss of urine [18]. The training of MAPs is defined as a program of repeated voluntary contractions of these muscles, taught and supervised by a health professional and is most commonly used as a physiotherapy treatment for women with stress urinary incontinence, but it is effective with all types of incontinence and is therefore recommended as a first line therapy [19 - 21], which is no different for men after radical prostatectomy [21], since the mechanism of continence is also dependent on the strength of the MAPs to increase the pressure of urethral closure, preventing urinary loss.

There are other methods that evaluate the strength of the MAPs, those considered as procedures for measuring the ability of pelvic muscle contraction, such as vaginal palpation, a method widely used clinically, but questioned for being subjective [22 - 24], the use of electromyography that measures the potential of action of the motor units that compose the muscle, but which has as a disadvantage beyond the high cost: the capture of the electric potential of muscles close to what is being evaluated - Crosstalk [22, 25, 26], the ultrasound in which it can be visualized the contraction of the MAPs in the caudal skull direction by the movement of the pelvic organs, but the studies are controversial as to its use for the evaluation of the MAPs, besides its high cost $[27,28]$ and the magnetic resonance that can also be used to evaluate it the strength of the MAPs, but also has the disadvantage of its high cost [29]. There are those that are related to the measurement of contraction, such as dynamometry that measures force in Newton (N) or kilogram-force (kgf), a method that would be ideal since it directly measures force, but so far the literature shows, besides studies in women only, the development of speculum dynamometers to collect their own studies which still limits clinical practice [30 - 35].

The present study presented as limitations the nonachievement of intra-rater reliability and inter-rater in internal consistency and inter-rater in stability; sample size $(n<50)$; perineometry is a voluntary test.

\section{Conclusion}

From the results of the present study, Peritron showed a high reliability to measure the strength of MAPs in men, both for clinical practice and for the production of scientific knowledge. It should be noted that such measures were performed in stability, therefore, it is suggested that in internal consistency its reliability is equivalent.

\section{References}

1. Bø K, Sherburn M. Evaluation of female pelvicfloor muscle function and strength. Phys Ther. 2005;85(3):269-82.

2. Kegel AH. Progressive resistance exercise in the functional restoration of the perineal muscles. Am J Obstet Gynecol. 1948;56(2):238-48.

3. Kegel AH. Physiologic therapy for urinary stress incontinence. J Am Med Assoc. 1951;46(10):915-7.

4. Laycock J. Clinical evaluation of the pelvic floor. In: Pelvic Floor Reeducation. London: Springer-Verlag; 1994.p. 42-8.

5. Parekh AR, Feng MI, Kirages D, Bremner H, Kaswick J, Aboseif S. The role of pelvic floor exercises on postprostatectomy incontinence. J Urol. 2003;170(1):130-3.

6. Kakihara CT, Sens YAS, Ferreira U. Efeito do treinamento funcional do assoalho pélvico associado ou não à eletroestimulação na incontinência urinária após prostatectomia radical. Rev Bras. Fisioter. 2007;11(6):481-6. 
7. Matheus WE, Ferreira U. Incontinência urinária no homem adulto. In: D'Ancona CAL. Princípios básicos de urodinâmica. São Paulo: Atheneu; 1995. p. 65-72.

8. Palma PCR. Incontinência urinária pós-prostatectomia. In: D'Ancona CAL, Netto Jr NR, Aplicações clínicas da urodinâmica. Campinas: Cartgraf; 1995. p. 273-80.

9. Hundley AF, Wu JM, Visco AG. A comparison of perineometer to brink score for assessment of pelvic floor muscle strength. Am J Obstet Gynecol. 2005;192(5):1583-91.

10. Moreira SFS, Girão MJBC, Sartori MGF, Baract EC, Lima GR. Mobilidade do colo vesical e avaliação funcional do assoalho pélvico em mulheres continentes e com incontinência urinária de esforço, consoante o estado hormonal. Rev Bras Ginecol Obstet. 2002;24(6):365-70.

11. Frawley HC, Galea MP, Phillips BA, Sherburn M, Bø K. Reliability of pelvic floor muscle strenght assessment using different test positions and tools. Neurourol Urodyn. 2006;25(3):236-242.

12. Barbosa PB, Franco MM, Souza FO, Antônio FI, Montezuma T, Ferreira CHJ. Comparison between measurements obtained with three different perineometers. Clinics (Sao Paulo). 2009;64(6):527-33.

13. Kottner J, Audigé L, Brorson S, Donner A, Gajewski BJ, Hróbjartsson A, et al. Guidelines for Reporting Reliability and Agreement Studies (GRRAS) were proposed. J Clin Epidemiol. 2011;64(1):96-106.

14. Brasil. Resolução CNS no 466, de 12 de dezembro de 2012. Estabeleceas diretrizes enormasbrasileiras regulamentadoras de pesquisas envolvendo seres humanos. [cited 2017 April 20]. Available from: https://tinyurl.com/yatq3pdd.

15. Messelink B, Benson T, Berghmans B, Bø K, Corcos J, Fowler C, et al. Standardization of terminology of pelvic floor muscle function and dysfunction: report from the pelvic floor clinical assessment group of the International Continence Society. Neurourol Urodyn. 2005;24(4):374-80.

16. Hopkins WG. Measures of reliability in sports medicine and science. Sports Med. 2000;30(1):1-15.

17. Ferreira CH, Barbosa PB, Souza FO, Antônio FI, Franco $\mathrm{MM}, \mathrm{B} \emptyset \mathrm{K}$. Inter-rater reliability study of the modified Oxford Grading Scale and the Peritron manometer. Physiotherapy. 2011;97(2):132-8.
18. Ashton-Miller JA, DeLancey JO. Functional anatomy of the female pelvic floor. Ann N Y Acad Sci. 2007;1101:266-96.

19. Dumoulin C, Hay-Smith EJ, Mac Habée-Séguin G. Pelvic floor muscle training versus no treatment, or inactive control treatments, for urinary incontinence in women. Cochrane Database Syst Rev. 2014;(5):CD005654.

20. Bø K. Pelvic floor muscle training in treatment of female stress urinary incontinence, pelvic organ prolapse and sexual dysfunction. World J Urol. 2012;30(4):437-43.

21. Abrams P, Cardoso L, Khoury S, Wein A. Incontinence. 5th ed. Paris: ICUD-EAU; 2013. p. 1908-12.

22. Bø K, Sherburn M. Evaluation of female pelvicfloor muscle function and strength. Phys Ther. 2005;85(3):269-82.

23. Bø K, Finckenhagen HB. Vaginal palpation of pelvic floor muscle strength: inter-test reproducibility and comparison between palpation and vaginal squeeze pressure. Acta Obstet Gynecol Scand. 2001;80(10):883-7.

24. Jeyaseelan SM, Haslam J, Winstanley J, Roe BH, Oldham JA. Digital vaginal assessment: an inter-tester reliability study. Physiotherapy. 2001;87(5):243-50.

25. Peschers UM, Gingelmaier A, Jundt K, Leib B, Dimpfl T. Evaluation of pelvic floor muscle strength using four different techniques. Int Urogynecol J Pelvic Floor Dysfunct. 2001;12(1):27-30.

26. Türker KS. Eletromyography: some methodological problems and issues. Phys Ther. 1993;73(10):698-710.

27. Thompson JA, O'Sullivan PB, Briffa NK, Neumann P. Assessment of voluntary pelvic floor muscle contraction in continent and incontinent woman using transperineal ultrasound, manual muscle testing and vaginal squeeze pressure measurements. Int Urogynecol J Pelvic Floor Dysfunct. 2006;17(6):624-30.

28. Braekken IH, Majida M, Engh ME, Bø K. Test-retest reliability of pelvic floor muscle contraction measured by 4D ultrasound. Neurourol Urodyn. 2009;28(1):68-73.

29. Artibani $\mathrm{W}$, Cerruto MA. The role of imaging in urinary incontinence. BJU Int. 2005;95(5):699-703.

30. Sampselle CM, Miller JM, Mims BL, DeLancey JO, AshtonMiller JA, Antonakos CL. Effect of pelvic muscle exercise on transient incontinence during pregnancy and after birth. Obstet Gynecol. 1998;91(3):406-12. 
31. Morin M, Dumoulin C, Bourbonnais D, Gravel D, Lemieux MC. Pelvic floor maximal strength using vaginal digital assessment compared to dynamometric measurements. Neurourol Urodyn. 2004;23(4):336-41.

32. Morgan DM, Kaur G, Hsu Y, Fenner DE, Guire K, Miller J, et al. Doesvaginal closure force differ in the the supine and standing positions? Am J Obstet Gynecol. 2005;192(5): 1722-8.

33. Verelst M, Leivseth G. Force and Stiffness of the pelvic floor as function of muscle length: a comparison between women with and without stress urinary incontinence. Neurourol Urodyn. 2007;26(6):852-7.

34. Morin M, Dumoulin C, Gravel D, Bourbonnais D, Lemieux MC. Reliability of speed of contraction and endurance dynamometric measurements of the pelvic floor musculature in stress incontinent parous women. Neurourol Urodyn. 2007;26(3):397-403.
35. Morin M, Gravel D, Bourbonnais D, Dumoulin C, Ouellet S. Reliability of dynamometric passive properties of the pelvic floor muscles in postmenopausal women with stress urinary incontinence. Neurourol Urodyn. 2008;27(8):819-25.

Received in 05/23/2017

Recebido em 23/05/2017

Approved in 02/16/2018

Aprovado em 16/02/2018 